Joseph N. Goh

Sharon A. Bong

Thaatchaayini Kananatu Editors

Gender and

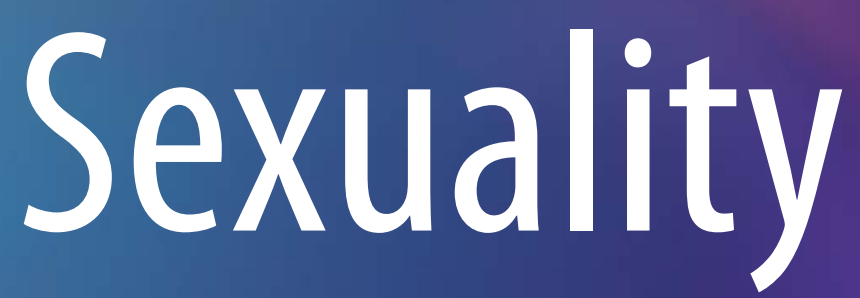

Justice in

Asia

Finding Resolutions through Conflicts

Springer 
Joseph N. Goh · Sharon A. Bong ·

Thaatchaayini Kananatu

Editors

\section{Gender and Sexuality Justice in Asia}

Finding Resolutions through Conflicts

Springer 


\section{Editors}

Joseph N. Goh

School of Arts and Social Sciences

Monash University Malaysia

Bandar Sunway, Malaysia

Thaatchaayini Kananatu

School of Business

Monash University Malaysia

Bandar Sunway, Malaysia
Sharon A. Bong

School of Arts and Social Sciences

Monash University Malaysia

Bandar Sunway, Malaysia

\section{ISBN 978-981-15-8915-7 ISBN 978-981-15-8916-4 (eBook) https://doi.org/10.1007/978-981-15-8916-4}

(C) The Editor(s) (if applicable) and The Author(s), under exclusive license to Springer Nature Singapore Pte Ltd. 2020

This work is subject to copyright. All rights are solely and exclusively licensed by the Publisher, whether the whole or part of the material is concerned, specifically the rights of translation, reprinting, reuse of illustrations, recitation, broadcasting, reproduction on microfilms or in any other physical way, and transmission or information storage and retrieval, electronic adaptation, computer software, or by similar or dissimilar methodology now known or hereafter developed.

The use of general descriptive names, registered names, trademarks, service marks, etc. in this publication does not imply, even in the absence of a specific statement, that such names are exempt from the relevant protective laws and regulations and therefore free for general use.

The publisher, the authors and the editors are safe to assume that the advice and information in this book are believed to be true and accurate at the date of publication. Neither the publisher nor the authors or the editors give a warranty, expressed or implied, with respect to the material contained herein or for any errors or omissions that may have been made. The publisher remains neutral with regard to jurisdictional claims in published maps and institutional affiliations.

This Springer imprint is published by the registered company Springer Nature Singapore Pte Ltd. The registered company address is: 152 Beach Road, \#21-01/04 Gateway East, Singapore 189721, Singapore 


\section{Contents}

\section{Part I Gender Justice in Asia}

1 Gender Inequality, Mainstreaming Strategies and Perpetual

Liminalities ............................... 3

Nadiah Ahmad

2 Hail Hijabis: Celebrification of Influencers by Postmodern

Malay-Muslim Women in Malaysia

Nurzihan Hassim and Siti Mazidah Mohamad

3 Gendering Adat Law: Women's Rights Activists in Balinese

Customary Affairs

Yogi Paramitha Dewi

4 Sexuality as Struggle: Michel Houellebecq and the South East

Asian Sex Trade

Klem James

5 Hindu Mothers and Muslim-Convert Fathers: Custody

Battles at the Intersection of Gender, Religion and Rights

in Malaysia

Thaatchaayini Kananatu and Juliana French

Part II Sexuality Justice in Asia

6 Constructing the (Homo)Sexual Self: Positioning in the Sexual Narratives of Filipino Gay Men . . . . . . . . . . . . . . . . . . . .

Christian Go

7 The Experience of Young LGBT People in Rural Vietnam Yen Hoang Ha

8 Beyond 'Butch': The Fluidity of Embodiment by Masculine-Identified Lesbians in Singapore Laura E. Wong 
9 Queer Women, Diplomacy and Security: A Case Study of Australian Leaders Deployed in the Asia Pacific Elise Stephenson

10 The Power of Transformation and Transforming Power:

A Malaysian Female-to-Male Transgender Person's Narrative Sharon A. Bong

11 Indonesian Christian Young People Resisting the Dominant Discourses of Men as Desiring/Dangerous and Women as Non-sexual/Vulnerable Teguh Wijaya Mulya

\section{Part III Finding Resolutions Through Conflict}

12 Fractured Social, Multiple Subjects: Reconceiving a Gender/Sexual Agent of Change

Wai Ching Angela Wong

13 Looking Queerly Through the Heart: Towards a Southeast Asian Praxis of Doing Church with LGBTIQ/PLHIV Joseph N. Goh

14 LGBT Equality and Thai Marriage $\ldots \ldots \ldots \ldots \ldots \ldots \ldots \ldots \ldots$ Douglas Sanders 


\title{
Chapter 11 \\ Indonesian Christian Young People \\ Resisting the Dominant Discourses \\ of Men as Desiring/Dangerous \\ and Women as Non-sexual/Vulnerable
}

\author{
Teguh Wijaya Mulya
}

\section{Introduction}

Contemporary feminist studies have identified the ways that gendered power relations have been the primary condition for intimate partner sexual violence (IPSV) to exist, be seen as normal, and therefore, sustained (Boonzaier 2008; Clarke 2012; DeShong 2015; Kitzinger 2003; Marcus 2002; Mehta and Bondi 1999; Robinson 2005). Significant early work in this area is Hollway's (1989) conceptualisation of the male sexual drive discourse and the have/held discourse. Through the male sexual drive discourse, men are constituted as 'naturally' having a high need for sex, being aggressive, and going to great lengths to have sex. In contrast, the have/held discourse positions women as 'naturally' passive, non-sexual and vulnerable to violence. Studies have revealed consequences of this dominant binary positioning, such as blaming the victim for not taking up the passive and non-sexual subject position (Boonzaier and de la Rey 2003, 2004; Hlavka 2014; Kiguwa et al. 2015; Mosha 2013; O’Neill 1998), the use of sexual violence to build masculine status (Boonzaier 2008; Robinson 2005), and the positioning of women as gate-keepers in managing the risks of IPSV (Carmody 2003; Marcus 2002).

While these previous studies have demonstrated how such binary positioning give rise to intimate partner sexual violence, there are only a few studies providing examples of resistance towards these gendered power relations. For instance, at the end of their articles, both DeShong (2015) and Boonzaier and de la Rey $(2003,2004)$ noted that female survivors of (hetero)sexual violence participating in their study showed a sense of strength and determination to challenge and overcome the violence they had experienced, refusing to be positioned as passive and vulnerable. There are also narratives from young men in Allen's (2003) and Wijaya Mulya's (2018) study who

T. Wijaya Mulya ( $₫)$

Faculty of Psychology, University of Surabaya, Surabaya, Indonesia

e-mail: teguh@staff.ubaya.ac.id 
challenged the construction of boys as 'naturally' only wanting sex in their relationships, drawing instead on a discourse of love and romance. Robinson (2005) discusses an alternative narrative from a male student who challenged traditional meanings of masculinity and sexual violence by joining a ballet club and standing up against heterosexist harassment considered trivial by most of his male friends. The purpose of this chapter is to extend the knowledge in this area by presenting underrepresented narratives of resistance which might rework this gendered positioning among young Indonesian Christians, particularly various contextual conditions-some of which have not been identified in previous studies - that have enabled them to resist those gendered power relations in their becoming sexual subjects.

In Indonesia, studies on IPSV have also identified this binary of men as desiring/dangerous and women as non-sexual/vulnerable as the discursive context from which IPSV occurred, particularly in heterosexual and marital contexts (Aisyah and Parker 2014; Bennett et al. 2011; Hakimi et al. 2001; Utomo et al. 2014). In Indonesia, such gendered binary have been supported by various cultural and religious discourses. Culturally, breaking the silence around marital sexual violence risks family honour by bringing shame to the whole family (Hayati et al. 2011; Idrus and Bennett 2003; Wieringa 2015). Indonesian researchers have also identified how certain interpretations of religious texts have supported gendered power relations, such as when a wife's complete submission to her husband is understood as a divine order (Munir 2005; Wijaya Mulya 2010). However, these previous studies only considered sexual violence within the context of heterosexual marriage, so that research on everyday sexual violence beyond this context is lacking. This chapter also seeks to extend existing studies by presenting and analyzing narratives of sexual violence from LGBT+ and heterosexual Indonesian young people, and examining different discursive contexts where those IPSV occurred, such as sexual violence by boyfriends and girlfriends.

\section{Methodological Notes}

The research adopts a feminist poststructuralist theoretical framework which considers that power, through the circulation of discourse, governs which waysof-seeing are deemed intelligible and which ways of being (i.e., subjectivity) are available in a society (Weedon 1987). It is predicated upon a premise that, since discourse both enables and constrains one's possibility to think, say, and do things, the cultivation of alternative subjectivity is a form of political resistance (Foucault $1978,1985)$. Such alternative subjectivity becomes possible because of the performative (Butler 1990) character of the subjectification process (Davies 2006), where one continuously draws on the available (multiple, shifting) discourses to give meaning to their experience. One's agency within this resistance is not understood as coming from one's own autonomous self, rather, one's agency lies in the ability to draw on alternative discourses to cultivate new ways of being (Davies 1991). Taking these 
poststructuralist theorisations of power, subjectivity and resistence into gender analysis, the purpose of a feminist poststructuralist research is, therefore, to identify, analyze and circulate alternative subjectivities and alternative discourses given rise to them (Willig 2013), in order to disrupt the dominant hetero-patriarchal discourses; which in this chapter, are alternative subjectivities that do not position men as sexually desiring/dangerous and women as non-sexual/vulnerable.

The study is a part of my doctoral research on contemporary Indonesian Christian young people's sexual subjectivity (Wijaya Mulya 2017), in which I interviewed 22 participants using computer-mediated research methods (i.e., email interview, instant messaging, and autobiographical writing). The interviews were conducted in Bahasa Indonesia and translated into English for this article. Twelve participants identified as male, nine as female and one as neither gender. Fourteen identified as heterosexual, 4 gay, 2 lesbian, 1 bisexual and 1 non-sexual. At the time of the interview, participants were college students (8 participants), high school students (6 participants), employees (5 participants), a freelance journalist (1 participant), a postgraduate student (1 participant) and an NGO activist (1 participant). All names used in this article are pseudonyms. Thematic data analysis technique (Braun and Clarke 2006) was applied to inductively analyse the data.

\section{Findings: Four Vignettes of Resistance Towards the Binary of Desiring/Dangerous Men and Non-sexual/Vulnerable Women}

Participants' narratives in this study display various examples of resistance towards the binary of men as sexually desiring/dangerous and women as nonsexual/vulnerable. Each of them have their own ways of opening up possibilities of alternative sexual subjectivity and also their own limitations. This section divides these resistances into four themes and discussed each or them in relation to discourses on IPSV. The analyses presented here are not intended to be representative nor exhaustive, but rather, to be disruptive towards the dominant discourses given rise to IPSV and encourage further exploration of alternative subjectivities.

\section{'Don't Push Me!': Women Standing Up Against the Desiring/Dangerous Men}

One participant who demonstrates a kind of resistance is Anggi (22, office worker, female, heterosexual), who has shared her story about how she successfully refused her ex-boyfriend' attempts to make her have sex with him. Anggi's narrative represents an image of woman that is courageous and unyielding-as opposed to vulnerable-in responding to a sexually coercive situation. 
It was not easy to refuse him [boyfriend] at that time. I was alone, this is unsafe actually, in my flat in another town. I was on a management trainee program there for a few months. That night we hung out, had dinner, then he drove me home to my flat. Yeah, a little cuddling, smooching, then it's going a bit further. But I stopped it when it started to move to the bed. We're still in our clothes. I said I'm not ready. He asked why. I repeated that I'm not ready. It was not easy to convince him. He kept asking why I'm not ready. He said, "Come on, I promise I'll be gentle." I replied, "I'm just not ready. Don't push me!" Then, because my voice was raised, he stopped. Well, I understand why he was like that. It's because he was sexually active with his ex. Then he met me, who made it clear that if I say no it means no, and don't even try to push me. (Email interview)

Reading Anggi's narrative through the binary of men as sexually desiring and women as vulnerable, it can be considered 'normal' for her boyfriend to ask for sex in this situation. Her decision to take her boyfriend to her flat alone after dinner and then have 'a little cuddling and smooching' might be interpreted as 'asking for it', so that it was not her boyfriend's fault if she was forced into sex. However, Anggi does not subscribe to this way of understanding sexual violence. Rather, she believes no one should engage in sexual activity unless it is completely consensual. She made it clear to him that keep asking her to have sex is offensive. Anggi does not consider a boyfriend pressuring his girlfriend as a 'normal' or 'everyday' matter, but as something to be taken seriously. Although she is considerate of his sexual history, it does not justify his attempt to make Anggi engage in sex without her full consent.

Drawing on the notion of 'sex must be consensual' has enabled Anggi to resist the positioning of women as vulnerable. Her narrative presents an example of how women need not be passive and weak, but able to speak up and stand up for what they believe. In her situation, the strategy of 'just say no' seemed to work, in that, it stopped her boyfriend. However, there are also limitations to this act of resistance. As feminist scholars have noted, the strategy of 'just say no' is problematic on several grounds (Gavey 2005; Holland et al. 1998). Firstly, it still locates the responsibility of preventing sexual violence to women. It reinforces the idea that men are 'naturally' desiring, so that women need to manage the risks of sexual violence by refusing or stopping them. In other words, women are still the 'gate-keepers' of sexual violence. This positioning of women leads to the next limitation of this strategy, that is, it still reproduces victim-blaming logic. Since women are the gate-keepers, they can be blamed if violence eventually occurs. It is still her fault for not stopping the violence from happening. Another limitation is that it still denies women as legitimate sexual subjects (Allen 2005). The strategy of 'just say no' implies that women do not have sexual desires, so that they can easily say 'no' because they have no desire to engage in sexual activity. This relocates women to the non-sexual subject position. The next subsection will discuss another vignette of resistance, which specifically challenges this presumed non-sexuality of women. 


\section{'It's Me Who Is Aggressive in This Relationship': Women Initiating and Taking Control of Sex}

Lusi (22, female, heterosexual) was a medical student when I interviewed her. She was in a relationship and has engaged in sex with her boyfriend. One of the main themes in her narrative is her identification of herself as sexually 'aggresive' - a word often used by Indonesia youth to refer to the more active and desiring partner in an intimate relationship. Below is her story around her sexual experience with her boyfriend which might pose a form of resistance towards the dominant binary of men as desiring and women as non-sexual:

Coming from a not-so-good family relationship, I want more love and intimacy. So I have
sex with my boyfriend. I think nowadays such a thing is quite common, depending in which
community you are. My boyfriend tends to be passive in our dating relationship. We've been
together for one year and he never took initiatives, even like holding my hand. Quite the
opposite, it is me who is aggressive in this relationship. The first time we did it was when
we went for a vacation. To save money we only booked one hotel room. A twin-bed. But
because of the hotel's mistake we ended up in a double-bed room. That was the first time we
slept together in a bed. At first nothing happened. We just slept at the opposite ends of the
bed because we were still shy. But because basically I'm an aggressive person, I started to
hug him and kiss his lips when we were on the bed. After a couple of vacations like that, our
relationship has developed into what we do now (i.e., sex). Usually when we want to do it,
we just book a hotel room. But most of the time, we did it when we were on vacation. I have
to hold myself back a little bit, because I know my boyfriend is a passive person. (Email
interview)

In a way Lusi's story is a reversal of Anggi's narrative, in that she-instead of being pressured to have sex-is the one who wanted, initiated, and took control of the sex. She even had to 'hold herself back a little bit' to balance the relationship with her boyfriend. Lusi also does not hesitate to label herself as 'aggressive' in her relationship, as compared to her boyfriend who is described as sexually 'passive' because he 'never took initiatives'. Lusi views her sexual engagement and initiative as 'normal' and common among her peers ("such a thing is quite common, depending in which community you are"). She expresses a sense of entitlement to her sexual desire (Fine 1988), in which she believes she deserved to experience love and intimacy through sex with her boyfriend because her family upbringing did not really satisfy her need for love and intimacy. The way Lusi understands herself as a sexual subject reversed the binary of men as sexually desiring and women as non-sexual. Her narrative demonstrates a reversal of this binary, in which she as a woman is positioned as desiring and her boyfriend as lacking in sexual desire.

This kind of reversal narrative is very rare in my research and previous research among Indonesian young people, and possibly rare more generally as well given the sexual mores of Indonesian society. In order to explore (discursive) conditions that might have given rise to her alternative subjectivity, here I will investigate Lusi's narrative closely particularly her family, religion and education backgrounds. Lusi describes herself as coming from a family that 'struggles financially' and her parents wanted their children to 'understand the condition'. Her parents demanded 'academic 
achievement' of their children so that they can have a better future. Her mother left for work in another town when she was 10 years old, and her father passed away when she was in high school. She describes her studying in medical school as the result of her hard academic work. She used to take care of herself and makes decisions independently quite early, such as when she decided to go to church alone riding her bicycle when her mother left for work in another town. She also decided to leave the church after she was disappointed with the lack of support from the church when her father passed away. Throughout the interviews, Lusi expressed herself as an independent, hard-working and courageous person. In terms of sexual experiences, Lusi explored and engaged in sex chats with foreigners when she was in intermediate school (Wijaya Mulya 2019). She started to think about having sexual intercourse when she studied at the university.

There was a subject on the biology of human development which taught me that desire for sex is basically normal. It is a normal human need. It's only the moral and religious values that repress this need. Some of my friends at uni often talked about their sexual experiences. What they think is quite the same with me: as long as you maximize the protection, sex is all right. (email interview)

By drawing on the biological discourse that sexual desire is 'normal' for a human being (not just for men), Lusi has been enabled to understand herself as a legitimate sexual subject who is entitled to engage in sex. This discourse is predominant among her friends at the university too, so that Lusi was able to see this understanding of sex as 'common' or 'normal'. Additionally, her disappointment with, and distancing from, the church has enabled her to doubt the authority of religious moral discourses that repress this 'human need' ("it's only the moral and religious values that repress this need"). Her family upbringing, religious experiences, university education and circle of friends in some ways have also contributed to her sense of independence and confidence in making decision, including her decision to engage in sex with her boyfriend.

However, Lusi's alternative sexual subjectivity that resists the binary of desiring men and non-sexual women also entails some limitations. One limitation is that it still operates within a heteronormative model of a sexual relationship, in which sexual relationship (including the possibility of sexual violence within it) occur among opposite sexes. The next subsection discusses another vignette of resistance towards this binary through a narrative of same-sex sexual violence.

\section{'Why It Has to Be Her Who Forced Me?:' Women and Same-Sex Sexual Violence}

Another participant in this study, Bianda (24, office worker, female, bisexual), demonstrated how disruption towards the binary of men as desiring/dangerous and women 
as non-sexual/vulnerable might be found in her difficulties to give meaning to samesex sexual violence. Below is her narrative about her experience of sexual coercion by her girlfriend, which might challenge the heteronormative foundation of this binary.

Bianda: My first time was when my ex [-girlfriend] forced me. She threatened to leave me if I refused. So I reluctantly did it.

Teguh: How do you feel about it?

Bianda: That first experience made me hate her, [I was] emotional, and regretful. I regretted why it has to be her, my ex, who forced me and not somebody else. But it is a lie if I say I didn't enjoy it. But still, in doing it I felt so unwilling. After that incident, I started to get used to doing it [sex]. I feel like I have broken my promise to myself [about not having sex], so what's the point, let's go all the way. But I make a new commitment: I will only have sex with women, not with men. (Instant messenger interview)

As previous studies have noted (Kramer 2015; Malinen 2013), same-sex sexual violence has disrupted the heteronormative assumptions behind the binary of men as desiring and women as non-sexual. Same-sex sexual violence is difficult to comprehend through this binary (Braun et al. 2009; Gilroy and Carroll 2009), such as the confusion among police officers regarding whom to arrest when they arrived at a scene after receiving a report of same-sex domestic violence (Knauer 1999). Similarly, this heteronormative binary cannot be drawn on to understand Bianda's experience of sexual violence on the part of her girlfriend: if women are passive and non-sexual, why did her girlfriend do it? Bianda's experience does not just position women as desiring, but also able to perform sexual violence-a situation which goes entirely against the positioning of women as non-sexual and vulnerable.

This situation might be heteronormalized again by designating the female perpetrator as taking up the 'male' role in the relationship. However, Bianda did not give meaning to her experience through such a way. Instead, Bianda finds her experience of sexual violence difficult to comprehend. She is confused as to why her intimate partner did it to her ("Why it has to be her, my ex, who forced me?"). In a way, being forced into sex by her girlfriend was unthinkable for her. Her girlfriend is a woman, not a man who is 'naturally' desiring and sexually aggressive. She was also unprepared to experience a mixture of feelings during the incident, such as how she used the phrase 'it is a lie if I say I didn't enjoy it' —as if she should not say it is enjoyable but because she wanted to be honest, she said it. Previous studies have documented that some survivors of sexual violence experienced a sensation of pleasure during the incident (Allen 2012; Angelides 2004; Ford 2009). Some of these survivors felt guilty about it, because such pleasure incited a degree of self-blame. To some extent Bianda also took the blame as seen in how she said she had broken her 'promise to not having sex', instead of her girlfriend forcing her. After the incident Bianda stayed in the relationship, and she consented to the subsequent sexual activities ("I started to get used to doing it."). As Elizabeth (2003) has noted, lacking discursive resources to understand sexual violence has made survivors unable to make decisions to leave or confront an abusive partner. Bianda's narratives show her experience of same-sex sexual violence has disrupted the heteronormative binary of men as desiring and 
women as non-sexual. However, the dominance of this binary has also resulted in a lack of other discourses for her to draw on in giving meaning to same-sex sexual violence.

\section{'From Tricking Girls to Pursuing Sexual Purity:' Evangelical Christian Men Disrupting IPSV but Reproducing Traditional Gender Roles}

So far, examples of contestation of the binary of desiring men and non-sexual women discussed here are from female participants. The final vignette presented will be a narrative from a male participant, Daniel (17, high school student, male, heterosexual). Daniel has engaged in sexual activities with his girlfriends in the past. Since he became a born-again Christian, his intense involvement in church activities has changed his way of seeing life, including sexuality. His narrative below demonstrates how the dominant meanings around men, women and sexual violence can be reworked, but at the same time also still reproduce this binary.

\footnotetext{
I have decided to repent and leave all my past sins. Through all the teaching, mentoring, and especially three Promise Keepers camps I have gone through, I have made a commitment to not tricking girls anymore. Now I believe that sex is created by God to be enjoyed in a true relationship (i.e., marriage). I know I am still weak and often fall in this sin, but I try as best I can to pursue purity. My heart becomes restless when I'm living in sin. Now I am always honest, no more lies in any relationships. I don't want to date girls anymore. Dating is only for fun, seeking reputation as a boy who can get many girls. Now I will only engage in a committed and respectful relationship. (Autobiographical writing)
}

Daniel has made a commitment to refrain from any sexual practices ("to pursue purity"), such as sexual intercourse, masturbation and pornography. One important milestone in this process is the Promise Keepers camp which he had attended three times. It is a worldwide evangelical Christian men's movement which promotes moral, spiritual and sexual purity (Claussen 2000; Donovan 1998; Williams 2001). In Indonesia, their camps and rallies were often conducted on a massive scale, and filled with strong messages, testimonies and challenges for men and boys to radically change their lives. Some of these challenges include a return to the functional role of father as the leader in the family, a promise to be faithful to their wives (or to be sexually abstinent before marriage), and most importantly, a commitment to pray, go to church and follow Jesus' example (Claussen 2000; Donovan 1998).

While the Promise Keepers movement and Daniel's narrative do not challenge traditional gendered power relations, they at least have opened up a possibility to rework the positioning of men as sexually desiring and dangerous in relation to sexual violence. Being a man is no longer associated with a 'Rambo-like figure who make sense [of] his world only through violence' (Deardorff 2000, p. 85). Instead, it is about love, integrity, faithfulness and 'leadership [over women] through humble servitude' (Deardorff 2000, p. 85). Here, violence becomes unacceptable for gaining masculine status (Flood 2015; Robinson 2005). As Hartley (1994, p. 99) puts it: 
'Our masculinity is not determined according to the size of our biceps. Instead, our masculinity is determined in part by how effectively we can embrace our wife and draw her close to our side'. Daniel articulates his redefinition of sex and masculinity by highlighting his commitment to 'not tricking girls anymore' and to engage with them in a 'committed and respectful relationship'. Drawing on this understanding of men, women and violence, the blame in an incident of sexual violence is now removed from the women survivors to men's failure to live in God's truth. While men's sexual desire is still understood as 'normal', the violent and unethical expressions of it are not. In this way, men and boys are acknowledged as sexual subjects, but these subjects also have to control their desires and pursue an abstinent lifestyle.

Daniel's narrative presents an alternative way to resist the normalization of sexual violence through the binary of men as desiring/dangerous and women as asexual/vulnerable. While his narrative in a way still reproduces this binary positioning of men and women, it rejects the normalization of sexual violence traditionally associated with it. By drawing on this redefinition of masculinity from a Christian evangelical movement, Daniel has been enabled to de-naturalize violence in young people's sexual relationships and focus on building respectful relationships.

\section{Conclusion}

To conclude, in this chapter I have discussed possibilities to contest the binary of desiring men and non-sexual women in the constitution of Indonesian Christian young people's sexual subjectivities. By illuminating how resistance might unfold in their becoming of sexual subjects empirically and contextually, this chapter seeks to provide everyday examples — not as a template to follow, but — as a means of enacting alternative possibilities of destabilizing dominant discourses underpinning intimate partner sexual violence.

It is important to note that each vignette of resistance discussed in this chapter always entails its own discursive limitations. For instance, Anggi's act of rebuking her boyfriend may reproduce the notion of women as gate-keepers, and Daniel's pursuit of sexual purity is based on and may perpetuate traditional gender roles. As in any other act of resistance, each practice that reworked the dominant discourses is always both enabling and limiting the subject in different ways. Readers are advised to be cautious in interpreting and applying the findings of this study.

The implication of this analysis is twofold. Firstly, parental and educational initiatives around IPSV prevention might find benefit in acknowledging non-traditional ways Indonesian young people understand themselves as sexual subjects. The image of desiring young woman like Lusi, for example, might be circulated and normalized with the purpose of relinquishing women from their gate-keeping role. Secondly, a recognition of the possibility of IPSV in various contexts other than marital and heterosexual ones-which future studies in Indonesia may also explore furthermight provide alternative discourses for young people to give meaning to their experience and, in turn, enable various preventive actions. Recognizing the possibility 
of IPSV in a lesbian relationship like Bianda's experience, for example, may enable young people to better prepare themselves against IPSV; but cautionary measures need to be considered so that it is not further demonizing LGBT+ sexualities in Indonesia.

\section{References}

Aisyah, S., \& Parker, L. (2014). Problematic conjugations: Women's agency, marriage and domestic violence in Indonesia. Asian Studies Review, 38(2), 205-223. https://doi.org/10.1080/10357823. 2014.899312.

Allen, L. (2003). Girls want sex, boys want love: Resisting dominant discourses of (hetero) sexuality. Sexualities, 6(2), 215-236. https://doi.org/10.1177/1363460703006002004.

Allen, L. (2005). Sexual subjects: Young people, sexuality, and education. Houndmills: Palgrave Macmillan.

Allen, L. (2012). Pleasure's perils? Critically reflecting on pleasure's inclusion in sexuality education. Sexualities, 15(3-4), 455-471. https://doi.org/10.1177/1363460712439654.

Angelides, S. (2004). Feminism, child sexual abuse, and the erasure of child sexuality. GLQ: A Journal of Lesbian and Gay Studies, 10(2), 141-177.

Bennett, L. R., Andajani-Sutjahjo, S., \& Idrus, N. I. (2011). Domestic violence in Nusa Tenggara Barat, Indonesia: Married women's definitions and experiences of violence in the home. The Asia Pacific Journal of Anthropology, 12(2), 146-163. https://doi.org/10.1080/14442213.2010. 547514.

Boonzaier, F. (2008). 'If the man says you must sit, then you must sit': The relational construction of woman abuse: Gender, subjectivity and violence. Feminism \& Psychology, 18(2), 183-206. https://doi.org/10.1177/0959353507088266.

Boonzaier, F., \& de la Rey, C. (2003). "He's a man, and I'm a woman": Cultural constructions of masculinity and femininity in South African women's narratives of violence. Violence Against Women, 9(8), 1003-1029. https://doi.org/10.1177/1077801203255133.

Boonzaier, F., \& de la Rey, C. (2004). Woman abuse: The construction of gender in women and men's narratives of violence. South African Journal of Psychology, 34(3), 443-463.

Braun, V., \& Clarke, V. (2006). Using thematic analysis in psychology. Qualitative Research in Psychology, 3(2), 77-101. https://doi.org/10.1191/1478088706qp063oa.

Braun, V., Schmidt, J., Gavey, N., \& Fenaughty, J. (2009). Sexual coercion among gay and bisexual men in Aotearoa/New Zealand. Journal of Homosexuality, 56(3), 336-360. https://doi.org/10. 1080/00918360902728764.

Butler, J. (1990). Gender trouble: Feminism and the subversion of identity. New York: Routledge.

Carmody, M. (2003). Sexual ethics and violence prevention. Social \& Legal Studies, 12(2), 199-216. https://doi.org/10.1177/0964663903012002003.

Clarke, H. (2012). Sexual harassment in higher education: A feminist poststructuralist approach. (Doctor of Philosophy), University of Derby, Derby.

Claussen, D. S. (Ed.). (2000). The Promise Keepers: Essays on masculinity and Christianity. Jefferson, NC: McFarland \& Company.

Davies, B. (1991). The concept of agency: A feminist poststructuralist analysis. Social Analysis, $30,42-53$.

Davies, B. (2006). Subjectification: The relevance of Butler's analysis for education. British Journal of Sociology of Education, 27(4), 425-438. https://doi.org/10.1080/01425690600802907.

Deardorff, D. (2000). Sacred male space: The Promise Keepers as a community of resistance. In D. S. Claussen (Ed.), The Promise Keepers: Essays on masculinity and Christianity (pp. 76-90). Jefferson, NC: McFarland \& Company. 
DeShong, H. A. F. (2015). Policing femininity, affirming masculinity: Relationship violence, control and spatial limitation. Journal of Gender Studies, 24(1), 85-103. https://doi.org/10.1080/095 89236.2013.833087.

Donovan, B. (1998). Political consequences of private authority: Promise Keepers and the transformation of hegemonic masculinity. Theory and society, 27(6), 817-843. https://doi.org/10.1023/ A:1006909132442.

Elizabeth, V. (2003). Separating from violent male partners: A resistant act in the midst of power relations. Journal of International Women's Studies, 4(3), 62-80.

Fine, M. (1988). Sexuality, schooling, and adolescent females: The missing discourse of desire. Harvard Educational Review, 58(1), 29-54. https://doi.org/10.17763/haer.58.1.u0468k1v2n2n 8242.

Flood, M. (2015). Work with men to end violence against women: A critical stocktake. Culture, Health \& Sexuality, 17(Suppl 2), 159-176. https://doi.org/10.1080/13691058.2015.1070435.

Ford, M. (2009, August 1). Heart and soul: Guilt, repentance and forgiveness, episode I the story of Colm O'Gorman who as a teenage boy was sexually abused by a Catholic priest. BBC World Service.

Foucault, M. (1978). The history of sexuality, vol. 1: The will to knowledge (R. Hurley, Trans.). New York: Pantheon Books.

Foucault, M. (1985). The history of sexuality, vol. 2: The use of pleasure (R. Hurley, Trans.). New York: Pantheon Books.

Gavey, N. (2005). Just sex? The cultural scaffolding of rape. London: Routledge.

Gilroy, P. J., \& Carroll, L. (2009). Woman to woman sexual violence. Women \& Therapy, 32(4), 423-435. https://doi.org/10.1080/02703140903153419.

Hakimi, E., Hayati, E. N., Marlinawati, V. U., Winkvist, A., \& Ellsberg, M. C. (2001). Membisu demi harmoni: Kekerasan terhadap istri dan kesehatan perempuan di Jawa Tengah, Indonesia (Silence for the sake of harmony: Domestic violence and women's health in Central Java, Indonesia). Yogyakarta, Indonesia: Rifka Annisa Women's Crisis Centre.

Hartley, F. (1994). Men and marriage. Minneapolis: Bethany House.

Hayati, E. N., Högberg, U., Hakimi, M., Ellsberg, M. C., \& Emmelin, M. (2011). Behind the silence of harmony: Risk factors for physical and sexual violence among women in rural Indonesia. BMC Women's Health, 11(1), 52-59. https://doi.org/10.1186/1472-6874-11-52.

Hlavka, H. R. (2014). Normalizing sexual violence: Young women account for harassment and abuse. Gender \& Society, 28(3), 337-358. https://doi.org/10.1177/0891243214526468.

Holland, J., Ramazanoglu, C., Sharpe, S., \& Thomson, R. (1998). The male in the head: Young people, heterosexuality and power. London: Tufnell.

Hollway, W. (1989). Subjectivity and method in psychology: Gender, meaning and science. London: Sage.

Idrus, N., \& Bennett, L. (2003). Presumed consent marital violence in Bugis society. In L. Manderson \& L. R. Bennett (Eds.), Violence against women in Asian societies (pp. 41-59). London: Routledge/Curzon.

Kiguwa, P., Nduna, M., Mthombeni, A., Chauke, P., Selebano, N., \& Dlamini, N. (2015). Half of the picture: Interrogating common sense gendered beliefs surrounding sexual harassment practices in higher education. Agenda: Empowering Women for Gender Equity, 29(3), 106-117. https:// doi.org/10.1080/10130950.2015.1052678.

Kitzinger, J. (2003). Creating discourses of 'false memory': Media coverage and production dynamics. In P. Reavey \& S. Warner (Eds.), New feminist stories of child sexual abuse: Sexual scripts and dangerous dialogue (pp. 94-107). London: Routledge.

Knauer, N. J. (1999). Same-sex domestic violence: Claiming a domestic sphere while risking negative stereotypes. Temple Political \& Civil Rights Law Review, 8(2), 325-350.

Kramer, S. (2015). Surfacing (im) possible victims: A critical review of the role of gender, sexuality and power in constructing the conditions of possibility for South African victims of female sex crimes. Sexualities, 18(3), 346-372. https://doi.org/10.1177/1363460714544808. 
Malinen, K. (2013). Thinking woman-to-woman rape: A critique of Marcus's "Theory and politics of rape prevention". Sexuality \& Culture, 17(2), 360-376. https://doi.org/10.1007/s12119-0129155-0.

Marcus, S. (2002). Fighting bodies, fighting words: A theory and politics of rape prevention. In C. L. Mui \& J. S. Murphy (Eds.), Gender struggles: Practical approaches to contemporary feminism (pp. 166-185). Lanham: Rowman \& Littlefield.

Mehta, A., \& Bondi, L. (1999). Embodied discourse: On gender and fear of violence. Gender, Place and Culture: A Journal of Feminist Geography, 6(1), 67-84. https://doi.org/10.1080/096636999 25150

Mosha, E. S. (2013). Discourse analysis of gender-based violence in contemporary Kiswahili fiction: A case study of selected novels of the past three decades (1975-2004) and young Tanzanians' interpretations. (Doctor of Philosophy), University of Waikato, Hamilton, NZ.

Munir, L. Z. (2005). Domestic violence in Indonesia. Muslim World Journal of Human Rights, 2(1), 1-37. https://doi.org/10.2202/1554-4419.1031.

O'Neill, D. (1998). A post-structuralist review of the theoretical literature surrounding wife abuse. Violence Against Women, 4(4), 457-490. https://doi.org/10.1177/1077801298004004005.

Robinson, K. H. (2005). Reinforcing hegemonic masculinities through sexual harassment: Issues of identity, power and popularity in secondary schools. Gender and Education, 17(1), 19-37. https://doi.org/10.1080/0954025042000301285.

Utomo, I. D., Utomo, A., Reimondos, A., McDonald, P., \& Hull, T. H. (2014). Young people's understanding of domestic violence: Evidence from a school based survey of Grade 6 and Grade 12 students in Indonesia. Genus, 70(2-3), 35-57. https://doi.org/10.4402/genus-544.

Weedon, C. (1987). Feminist practice and poststructuralist theory. Oxford: Blackwell.

Wieringa, S. E. (2015). Gender harmony and the happy family: Islam, gender and sexuality in postreformasi Indonesia. South East Asia Research, 23(1), 27-44. https://doi.org/10.5367/sear.2015. 0244.

Wijaya Mulya, T. (2010). Thou should submit to your husband: Gender-role ideology of church leaders in Indonesia. Paper presented at the 2nd Congress of Asian Association of Women Studies, Penang, Malaysia.

Wijaya Mulya, T. (2017). From divine designation to discursive contestation: The constitution of Indonesian Christian young people's sexual subjectivities. (Doctor of Philosophy), University of Auckland, New Zealand.

Wijaya Mulya, T. (2018). From divine instruction to human invention: The constitution of Indonesian Christian young people's sexual subjectivities through the dominant discourse of sexual morality. Asian Studies Review, 42(1), 53-68. https://doi.org/10.1080/10357823.2017.1407918.

Wijaya Mulya, T. (2019). From vulnerable to responsible youth? Indonesian youth resisting the dominant discourse of sexual health. Psychology and Sexuality (Advanced online publication), 1-13. https://doi.org/10.1080/19419899.2019.1604566.

Williams, R. H. (Ed.). (2001). Promise keepers and the new masculinity: Private lives and public morality. Lanham, MD: Lexington Books.

Willig, C. (2013). Introducing qualitative research in psychology. Berkshire: Open University Press.

Teguh Wijaya Mulya is a lecturer in psychology at the University of Surabaya, Indonesia. He is a graduate of the University of Surabaya (Bachelor of Psychology); Monash University, Australia (Master of Education); and the University of Auckland, New Zealand (Doctor of Philosophy). He specialises in research in the areas of sexuality, gender, religion, and neoliberalism. His work is inspired by the work of Michel Foucault and post-structuralist feminism. His research has been published in reputable journals including British Journal of Religious Education; Asian Studies Review; Culture, Health, and Sexuality; Media Psychology; Sexuality \& Culture; and International Journal for Academic Development. 